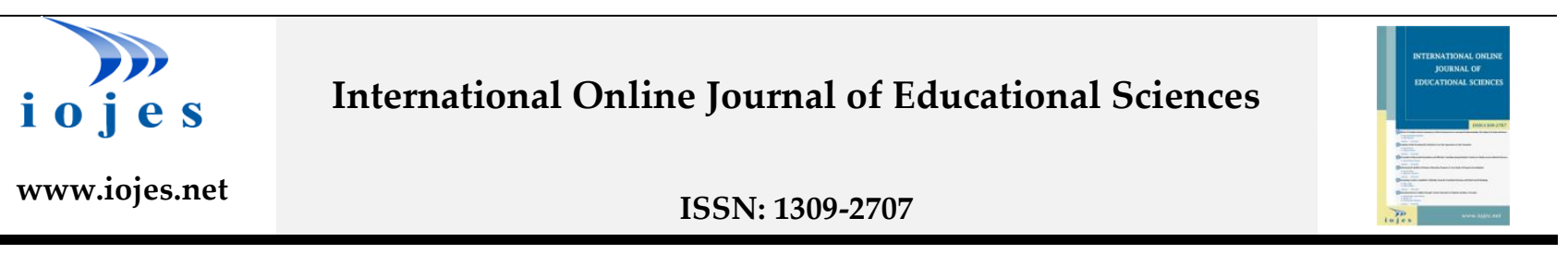

\title{
Analysis of Coursebooks Used in Teaching Turkish as A Foreign Language in The Context of Intercultural Communicative Competence
}

\section{Research Article}

\section{Latif ILTAR ${ }^{1}$}

${ }^{1}$ Ankara Yildirm Beyazıt University, DILMER, Ankara, Turkey, ORCID: 0000-0002-2807-8083

To cite this article: Iltar, L. (2021). Analysis of coursebooks used in teaching Turkish as a foreign language in the context of intercultural communicative competence, International Online Journal of Educational Sciences,

13(1), 205-217.

\section{ARTICLE INFO \\ Article History:}

Received: 08.12.2020

Available online:

10.01.2021

\begin{abstract}
The most rudimentary teaching materials in foreign language education are textbooks. The textbooks aim to create awareness about the target culture to a certain extent while teaching the target language's vocabulary and linguistic structures. Along with activities that convey information about the target culture, touching upon their culture, making them feel that this culture is valuable, and thus creating awareness about the value as to all cultures in the eyes of the learner enables the language learner to develop a positive attitude towards the target culture. In this sense, it is essential to touch upon learners' own cultures in the teaching process to develop intercultural communicative competence and, thus, develop positive attitudes towards the target culture. In this study, the question "To what extent is intercultural communicative competence included in the textbooks used in teaching Turkish as a foreign language?" will be dealt with. The study's research model was determined qualitatively, and the document analysis method was used to determine the data. The sample of the study consists of the Turkish Teaching Course Book - Yedi İklim Türkçe Öğretim Seti (YITÖS) B2 Level prepared by Yunus Emre Institute, which is widely used in the field, and the Istanbul Turkish Teaching Course Books for Foreigners (İTÖS) B2 Level prepared by Istanbul University academic staff. As a result of the analysis of the data, it was determined that the ratio of the number of activities supporting intercultural communicative competence to the total number of activities was $7 \%$ in the İTÖS B2 textbook and $8 \%$ in the YİTÖS B2 textbook. Besides, it has been determined that activities containing elements that might support intercultural communicative competence gain more weight in both coursebooks' productive skills.
\end{abstract}

(C) 2021 IOJES. All rights reserved

Keywords:

Teaching Turkish as a foreign language, Intercultural communicative competence, Interculturality, Turkish teaching course books.

${ }^{1}$ Corresponding author's address: Ankara Yıldırım Beyazıt Üniversitesi

Telephone: +905321662645

e-mail: liltar@ybu.edu.tr

DOI: https://doi.org/10.15345/iojes.2021.01.014 


\section{Introduction}

Culture is unique and peculiar to all nations and is the most fundamental feature that distinguishes a nation from other nations. Culture enables people to understand each other by gathering people in a community around common goals. People within the same culture can communicate well by developing common attitudes and behaviors. To create unity in attitudes and behaviors, they must meet on a shared cultural objective. People born in the same cultural community have a significant advantage in establishing healthy communication as they have common attitudes and behaviors in general. However, there might be differences in people born in different cultural communities because of their cultural differences, which may prevent healthy communication. In order for the communication between individuals from different cultural communities to operate in a healthy way, individuals must demonstrate a respectful approach to other cultures apart from their own culture. Being able to demonstrate a respectful approach to other cultures is directly related to intercultural communicative competence.

Thanks to the technological advances experienced today, people can become aware of different cultures more intensely than they could in the past. While it was possible for people to be more aware of the existence of different cultures through migrations in the past, today, people have the opportunity to be aware of the existence of other cultures thanks to the mass media tools. Until the 19th century, the survival rates in monocultural environments were relatively high, while being in diverse cultural groups increased considerably as of the 20th century. Today, owing to many reasons, such as economy, security, education, health, tourism, etc., people from different cultures can coexist in masses or individually. While individuals with different cultures coexist, differences in attitudes and behaviors may occur, and communicative problems may be encountered.

Specific cultural policies have been developed and put into practice by the states to enable people from different cultures to live together without any problems, primarily due to mass migration. When the cultural policies imposed by the states are examined, it is seen that these policies consist of unilateral cultural transfer, multiculturalism, and interculturalism practices. While the unilateral cultural transfer is based on dominant or prevailing culture, multiculturalism draws boundaries between cultures and treats cultures separately from each other. Interculturality is based on the interaction of cultures (İltar, 2020, p. 46).

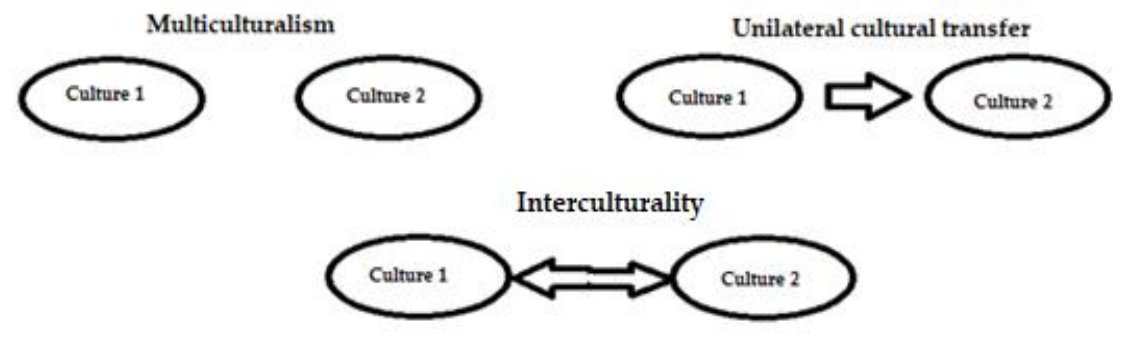

Figure 1. The difference between multiculturalism, unilateral culture transfer and interculturality.

İltar, L. (2020). Kültürlerarası İletişimsel Dil Yeterliği Bağlamında Gö̧̧menlere Türkçe Öğretimi. Başar, U., \& Tüfekçioğlu B. (Ed.) Göçmelere Türkçe öğretimi içinde. Ankara: Nobel.

Among the unilateral cultural transfer, multiculturalism, and interculturalism practices, interculturalism is the most current practice. Interculturality has gained meaning after multiculturalism. (Çötok, 2010, p. 19). Shortly after introducing multiculturalism policies in most of the EU countries, it turned into an uncertain future by encountering opposition from political powers and ordinary people, and thus a multiculturalism crisis emerged (Özbudun, 2014, p. 77). Multiculturalism deepens the boundaries between 
each other by dividing cultures into segments. In multiculturalism, culture is considered that it belongs to a specific ethnic group and is regarded as the sole property of that ethnic group. Since cultures are determined as independent units, they risk overemphasizing boundaries and differences (Kaya \& Kentel, 2005, p. 78).

Interculturality is based on the interaction between cultures and the individuals belonging to the cultures to recognize each other's cultures. In this context, interculturalism includes societies' practices to live together smoothly by respecting each other's cultures. Interculturalism has an important place in foreign language teaching and other fields such as sociology, psychology, and anthropology.

Language, which is the most important means of communication between people, is the essential element of culture. Culture can be transmitted from generation to generation through language. While language enables people to express their feelings and thoughts, it carries traces of culture within each element. For this reason, it is impossible to consider language separately from culture, and it is necessary to attach importance to the use of cultural elements in the studies regarding language education and teaching. Today, the necessity of transferring cultural elements in language education and teaching studies is understood by almost everyone. However, there is no consensus about how cultural elements should be transferred.

One-sided/unilateral cultural transfer comes to mind when it comes to integrating cultural elements in teaching Turkish as a foreign language. In foreign language teaching, although the transfer of target culture elements is essential, it is necessary to include the learners' own cultures and the target culture to ensure the learner's motivation and achieve positive attitudes regarding the culture of the target language. The learner should be reminded in the language teaching process that the learner's own culture is also valuable, and students should be made aware that each culture has a unique value. Thus, a language learner should be prevented from developing a negative attitude towards the language he or she has learned, and it should be ensured that they learn the cultural elements of the language they study and develop positive attitudes and behaviors towards them.

\section{Scope of the Study}

This study aims to examine the textbooks used in teaching Turkish as a foreign language in the context of intercultural communicative competence.

\section{Problems}

The study's major problem statement, "To what extent is intercultural communicative competence included in the textbooks used in teaching Turkish as a foreign language?" constitutes our question here. In addition to this problem statement, the study also seeks answers to the following sub-questions:

(-) What is the ratio of the number of activities in which intercultural communicative competence is included in the textbooks used in teaching Turkish as a foreign language to the total number of activities?

(-) What is the rate of difference between the textbooks among the activities in which intercultural communicative competence is included in the textbooks used in teaching Turkish as a foreign language?

(-) What is the rate of the four basic language skills in intercultural communicative competence in the textbooks used in teaching Turkish as a foreign language?

\section{Method}

\section{Research Model}

This study's research model aims to determine to what extent intercultural communicative competence is included in the textbooks used in teaching Turkish as a foreign language, was determined qualitatively. There seems to exist an anti-positivist perspective based on qualitative research. The researcher reaches the 
facts through his knowledge and experience. The researcher can bring a different perspective to these facts with his personal opinion. In qualitative research, the aim is not to generalize but to examine the events in depth (Baysal \& Hocaoğlu, 2019, p. 126). In the study, the document analysis method was used to determine the data. Document review covers the analysis of written materials containing information about the phenomenon or phenomena aimed to be investigated (Yıldırım \& Şimşek, 2016, p. 189).

\section{Universe and Sample}

The textbooks used in teaching Turkish as a foreign language constitute the universe of the study. Textbooks are one of the teaching materials that are a source of learning experiences in order to realize their educational goals, and even often the only teaching material (Toprak, 2011, p. 13). The absence of an existing program or curriculum in teaching Turkish as a foreign language makes the role of textbooks in the teaching process even more significant. In this context, textbooks act as teaching guides that draw the curriculum's general framework (Korkmaz, 2019, p. 122). Since qualitative research is time-consuming, small samples are usually studied in such studies (Gürbüz \& Şahin, 2017, p. 103). The study sample consists of the activities in the Yedi İklim Turkish Teaching Set B2 textbook prepared by Yunus Emre Institute, which is widely used in the field, and the Istanbul Turkish Teaching Set B2 textbook, which was prepared by Istanbul University academic staff.

It has been determined by Erdil (2018, p. 108) that the most commonly used three course books at tertiary level are Yedi İklim Türkçe Öğretim Seti, İstanbul Yabancılar İçin Türkçe Öğretim Seti and Gazi Yabancılar için Türkçe Öğretim Seti. It was revealed in the study that Yedi İklim Türkçe Öğretim Seti was used in 33 universities, İstanbul Yabancılar İçin Türkçe Öğretim Seti in 17 universities, and Gazi Yabancılar için Türkçe Öğretim Seti was used in 17 universities. For this reason, the two textbooks to be used in the sample of the study were selected, which are; Yedi İklim Türkçe Öğretim Seti and İstanbul Yabancılar İçin Türkçe Öğretim Seti.

It is necessary to be careful in using the elements of the culture of the target language at A1, A2, and B1 levels, where the language is just beginning to be learned and the early stages of getting acquainted with the culture of the language learned. At the A1, A2, and B1 levels where the language is just beginning to be learned, it should be tried to raise awareness about the target culture by using more universal cultural elements (IItar, 2020, p. 50). Cultural elements of the language are not encountered at basic levels since learners cannot meet the language's basic requirements; however, learning objectives as to the target linguistic competence to be reached at the intermediate and advanced levels seem more accurate (Kalfa, 2013, p. 177). Although it is known that cultural elements should be transferred to students at all levels, it was thought that it would be more accurate to examine B2 levels in the textbooks selected as a sample since the elements of the target culture can be used more widely as of the B2 level.

\section{Data Collection and Analysis}

In order to determine the extent to which intercultural communicative competence is included in the textbooks used in teaching Turkish as a foreign language, the activities in the B2 textbook in the Yedi Iklim Türkçe Öğretim Seti and İstanbul Yabancllar İçin Türkçe Öğretim Seti were analysed through the method of document analysis and the results obtained as a result of the analysis were expressed in percentages. While any activity in the textbooks is regarded as valuable in intercultural communicative competence, the inclusion of different cultures and learners' own cultures is taken into account except for the target culture and universal culture.

Although "numbering" was taken as a basis in determining the number of activities in the textbooks, it was also observed that some activities were not numbered and yet some of these activities supported intercultural communicative competence. Activities consisting of "What About You?", "From Culture to Culture" and "Let's Learn with Fun," which are created entirely independent of the activities enumerated in 
the İstanbul Yabanclar İçin Türkçe Öğretim Seti, have been included in the total number of activities. In the Yedi İklim Türkçe Öğretim Seti, the activities that were created entirely independent of the numbered activities and that include the titles "Preparation for the Unit" and "Free Reading" included in each unit were added to the total number of activities.

\section{Findings}

\section{Numerical and Percentage Distribution of the Activities that Include Elements Supporting Intercultural} Communicative Competence in Textbooks Used in Teaching Turkish as a Foreign Language

The activities in the Yedi İklim Türkçe Öğretim Seti and İstanbul Yabancılar İçin Türkçe Öğretim Seti B2 levels were examined and graphed in terms of numerical and percent value as to whether they include elements that support intercultural communicative competence.

\section{Distribution of the Number of Activities Supporting Intercultural Communicative Competence in İTÖS} B2 Textbook by Units

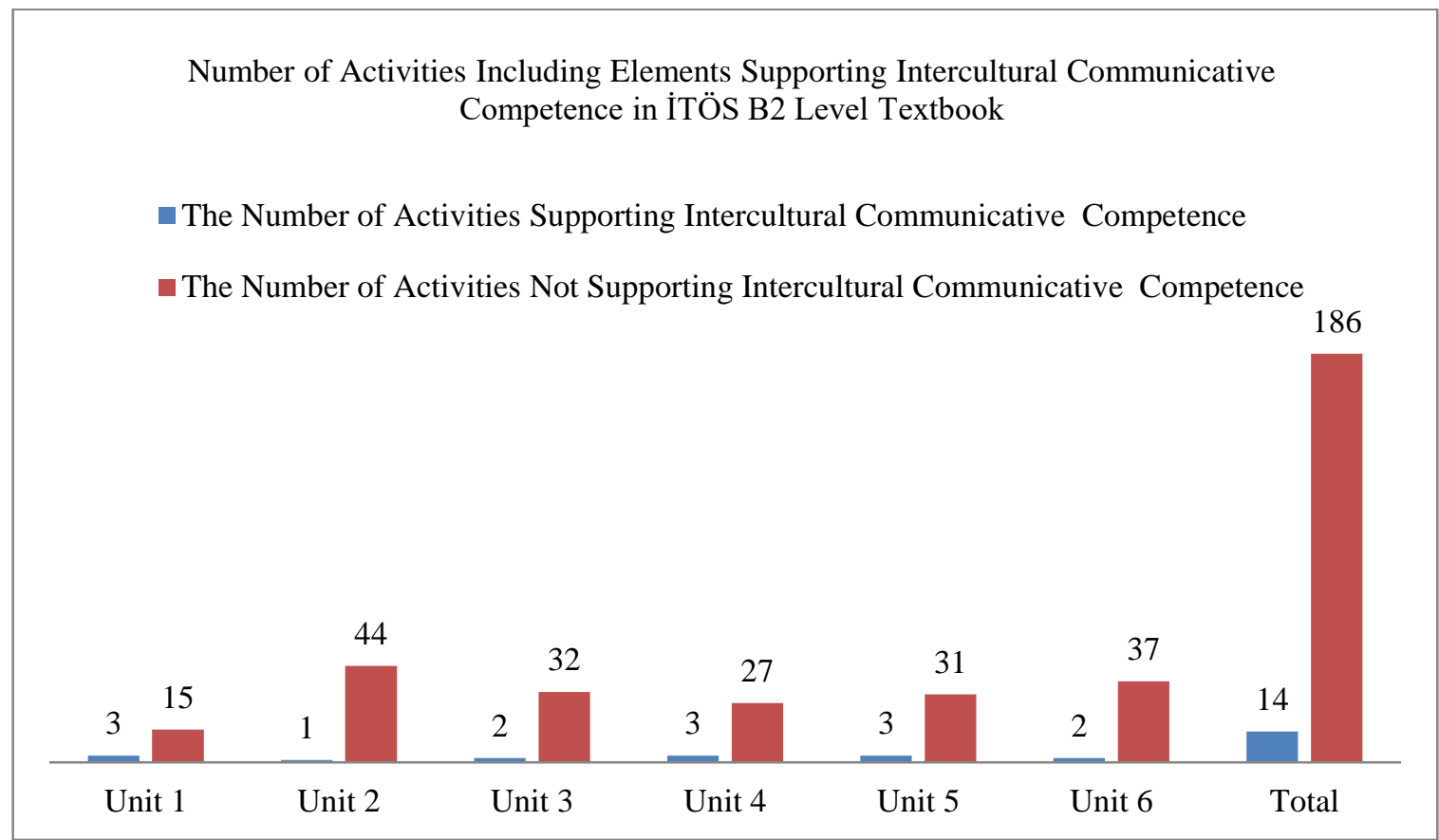

Figure 2. Distribution of the number of activities that support the intercultural communicative competence in the İTÖS B2 Level Textbook by units

There are six units in the İTÖS B2 coursebook, and each unit consists of three sections. The B2 textbook, which consists of two hundred activities in total, includes elements that support intercultural communicative competence within 14 activities.

At the end of each unit, there is an activity titled "From Culture to Culture," and all of these activities contain elements that support intercultural communicative competence. Although Unit 2 has the highest number of activities, it is the unit with the least number of activities in intercultural communicative competence. Unit 2 contains only elements that support intercultural communicative competence within the activity named "From Culture to Culture." This shows no positive correlation between the total number of activities and the number of activities that support intercultural communicative competence. 


\section{Percentage Distribution of the Activities Supporting Intercultural Communicative Competence in the} İTös B2 Textbook

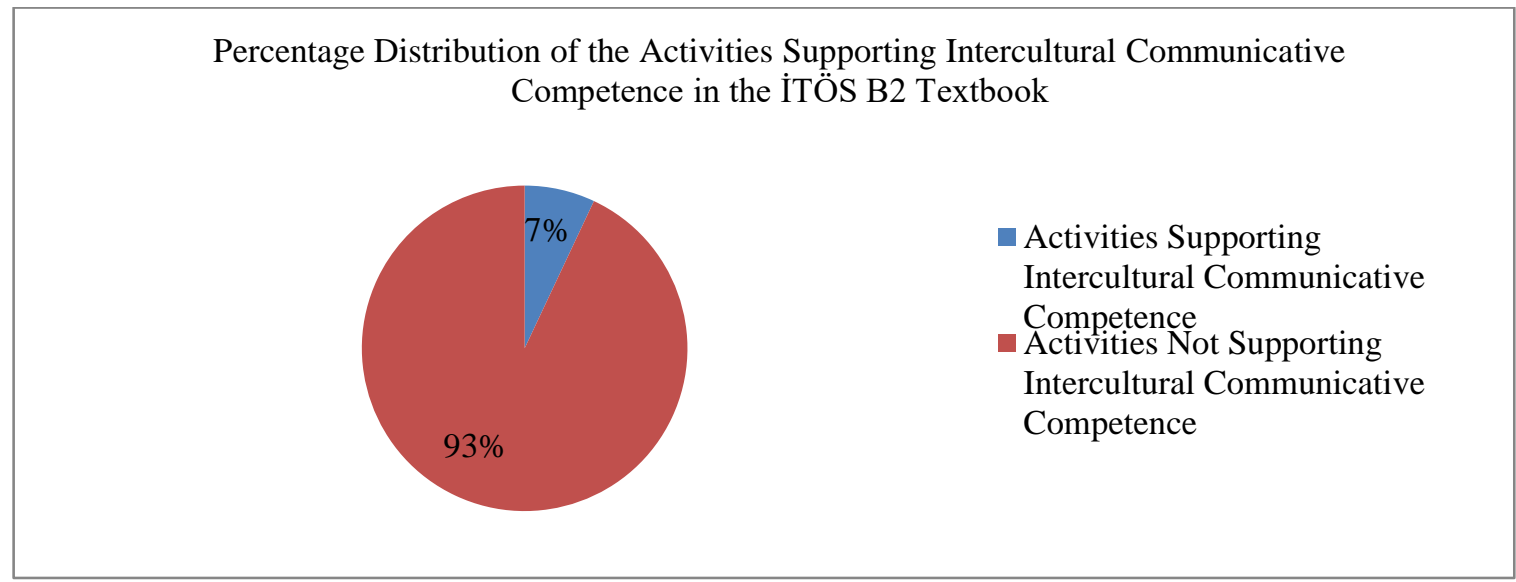

Figure 3. Percentage Distribution of the Activities Supporting Intercultural Communicative Competence in the İTÖS B2 Textbook

When the activities in the İTÖS B2 textbook are examined, it is seen that $93 \%$ of the activities do not include elements that support intercultural communicative competence, and only $7 \%$ are included. It has been determined that almost all of the activities do not include elements that support intercultural communicative competence.

Distribution of the Number of Activities Supporting Intercultural Communicative Competence in YíTÖS B2 Textbook by Units

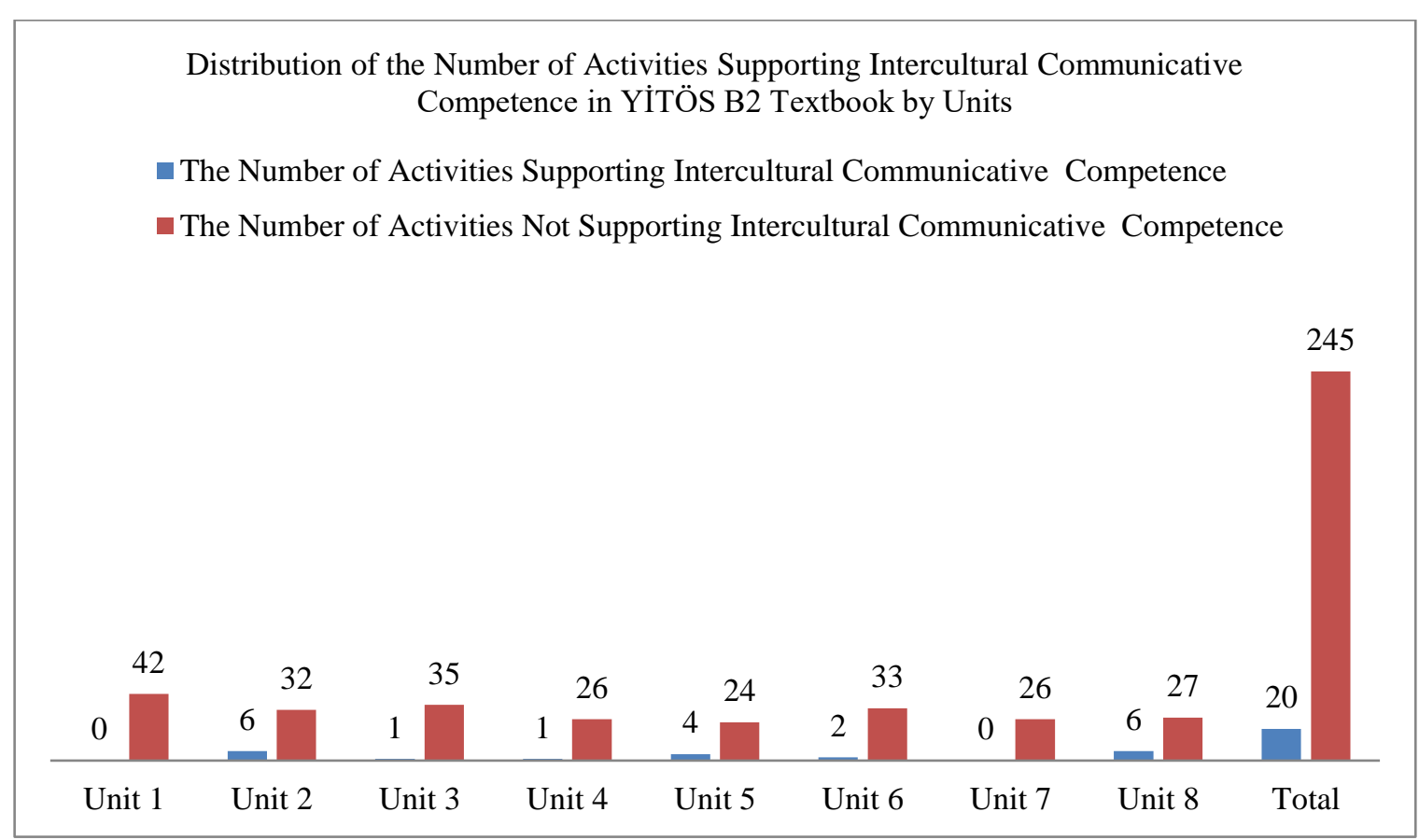

Figure 4. Distribution of the Number of Activities Supporting Intercultural Communicative Competence in YİTÖS B2

$$
\text { Textbook by Units }
$$

There are eight units in the YITÖS B2 textbook, and each unit consists of three sections. The B2 textbook, which consists of 245 activities in total, includes the element supporting intercultural communicative competence within 20 activities.

No activity supports intercultural communicative competence in Units 1 and 7. Although Unit 1 contains the highest number of activities, it is the unit with the least number of activities in intercultural 
communicative competence, showing that there is no positive correlation between the total number of activities and the number of activities that support intercultural communicative competence.

\section{Percentage Distribution of the Activities Supporting Intercultural Communicative Competence in the YİTÖs B2 Textbook}

Percentage Distribution of the Activities Supporting Intercultural Communicative Competence in the YİTÖS B2 Textbook

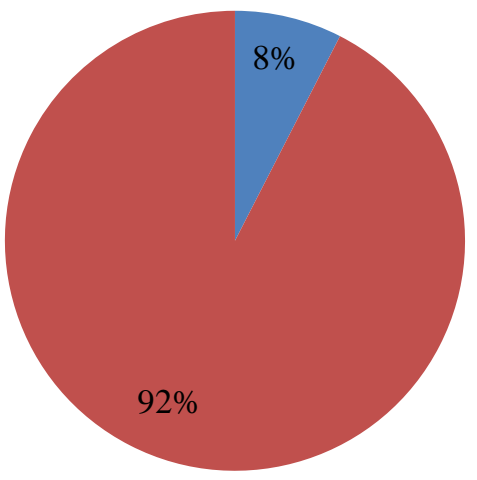

The Activities Supporting Intercultural Communicative Competence

- The Activities Not Supporting Intercultural Communicative Competence

Figure 5. Percentage Distribution of the Activities Supporting Intercultural Communicative Competence in the YITÖS B2 Textbook

When the YİTÖS B2 textbook activities were examined, it was found that $92 \%$ of the activities did not include elements that support intercultural communicative competence, and $8 \%$ were included. In almost all of the activities, elements that support intercultural communicative competence have not been included.

The Inclusion Rates of Textbooks Used in Teaching Turkish as a Foreign Language According to Instruction Sets, Intercultural Communicative Competence

The extent to which the activities in the B2 textbooks in the Yedi İklim Türkçe Öğretim Seti and İstanbul Yabancılar İçin Türkçe Öğretim Seti include the elements that support the intercultural communicative competence are shown in the graphics comparatively.

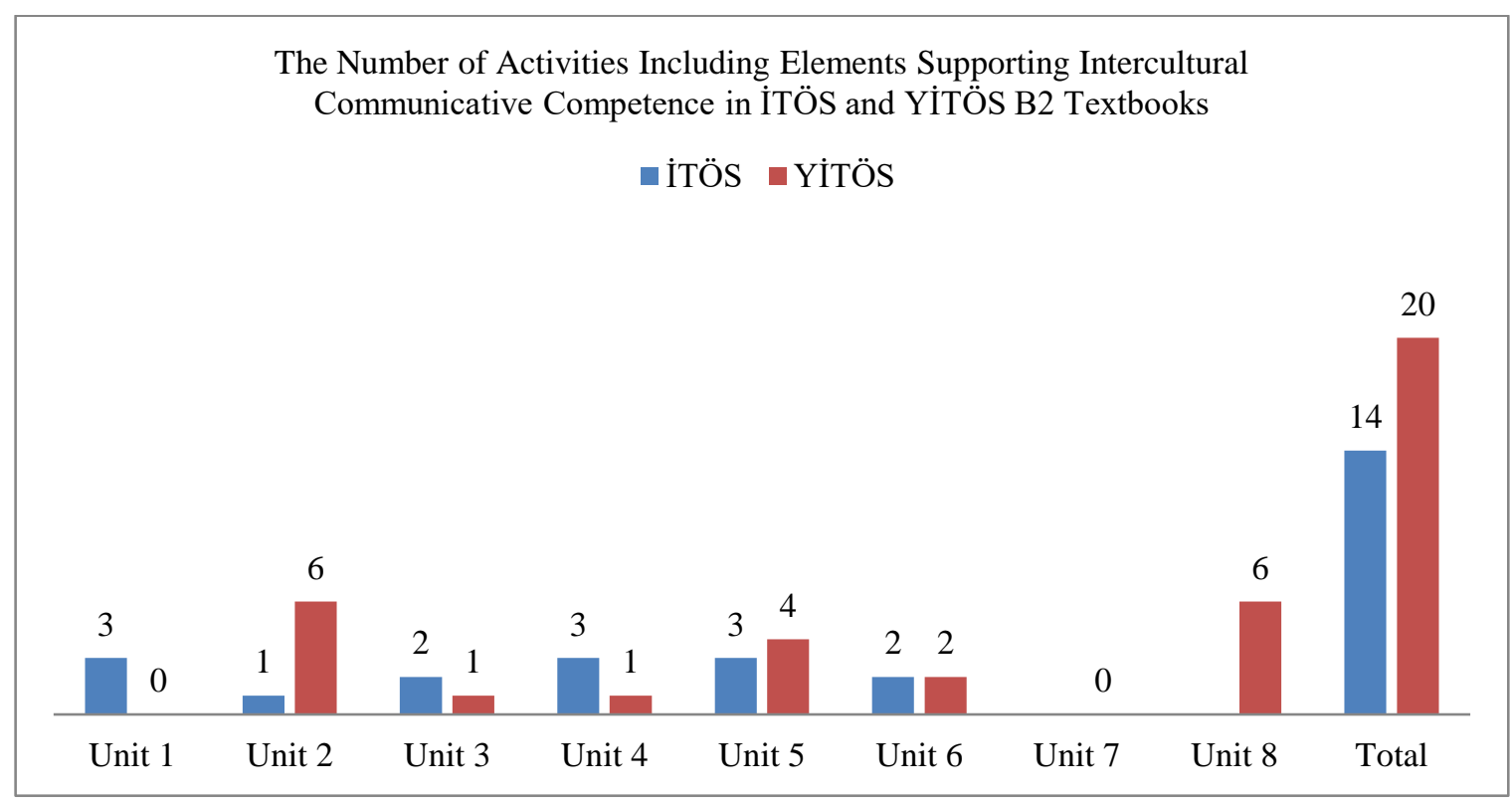

Figure 6. The Number of Activities Including Elements Supporting Intercultural Communicative Competence in İTÖS and YİTÖS B2 Textbooks 
While the İTÖS B2 coursebook consists of six units, the YİTÖS B2 coursebook consists of eight units. For this reason, there is no activity in the seventh and eighth units in the ITÖS B2 textbook. Intercultural communicative competence is supported in 14 activities in İTÖS and 20 activities in YİTÖS. When the first six units of the textbooks of both teaching sets are evaluated, it is seen that there are 14 activities in both textbooks.

It is seen that there are elements that support intercultural communicative competence in the activities titled "From Culture to Culture" in each unit of İTÖS. Thus, elements that support the intercultural communicative competence are included in each unit, at least in one activity. It is seen that the YİTÖS B2 textbook does not include any element that supports intercultural communicative competence in the first and seventh units.

The activities titled "From Culture to Culture" included in each unit of the İÖS B2 textbook have provided the inclusion of elements that support intercultural communicative competence in each unit. This shows that the intercultural communicative competence was taken into account in preparing the İTÖS B2 textbook. There are activities titled "Free Reading" at the end of each unit in the YİTÖS B2 textbook. Although not all of these activities, most of them contain elements of Turkish culture. Although in some, similar elements in their own cultures were asked to the learners. However, not all "Free Reading" activities are included. The fact that the YİTÖS B2 textbook does not include elements that support intercultural communicative competence in some units shows that intercultural communicative competence was not taken into account in the book's preparation.
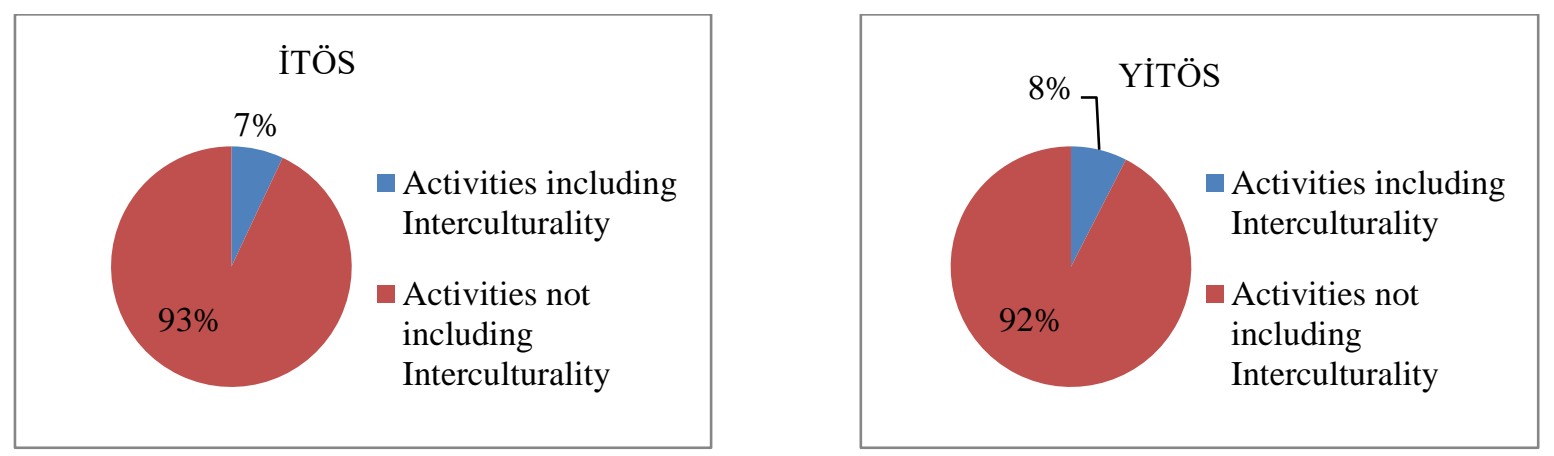

Figure 7. Activities rate that includes elements supporting intercultural communicative competence in the İTÖS and YİTÖS B2 Textbooks

When the activities in the İTÖS and YİTÖS B2 textbooks that include elements that support intercultural communicative competence are compared proportionally, it is seen that the ratio in both textbooks is very close to each other. While the efficiency rate supporting interculturalism in İTÖS B2 textbook is $7 \%$, this rate is $8 \%$ in the YİTÖS B2 textbook, which shows that intercultural communicative competence is given very little room in both teaching sets.

\section{Numerical and Percentage Distribution of Activities that Include Supporting Elements of Intercultural Communicative Competence in Textbooks Used in Teaching Turkish as a Foreign Language by Language Skills}

The activities in Yedi İklim Türkçe Öğretim Seti and İstanbul Yabancllar İçin Türkçe Öğretim Seti B2 level were examined, and the language skills of the activities that support the intercultural communicative competence were shown in the graphics as numerical and percent values. 


\section{Numerical Distribution of Activities that Include Elements Supporting Intercultural Communicative} Competence in İTÖS B2 Textbook by Language Skills

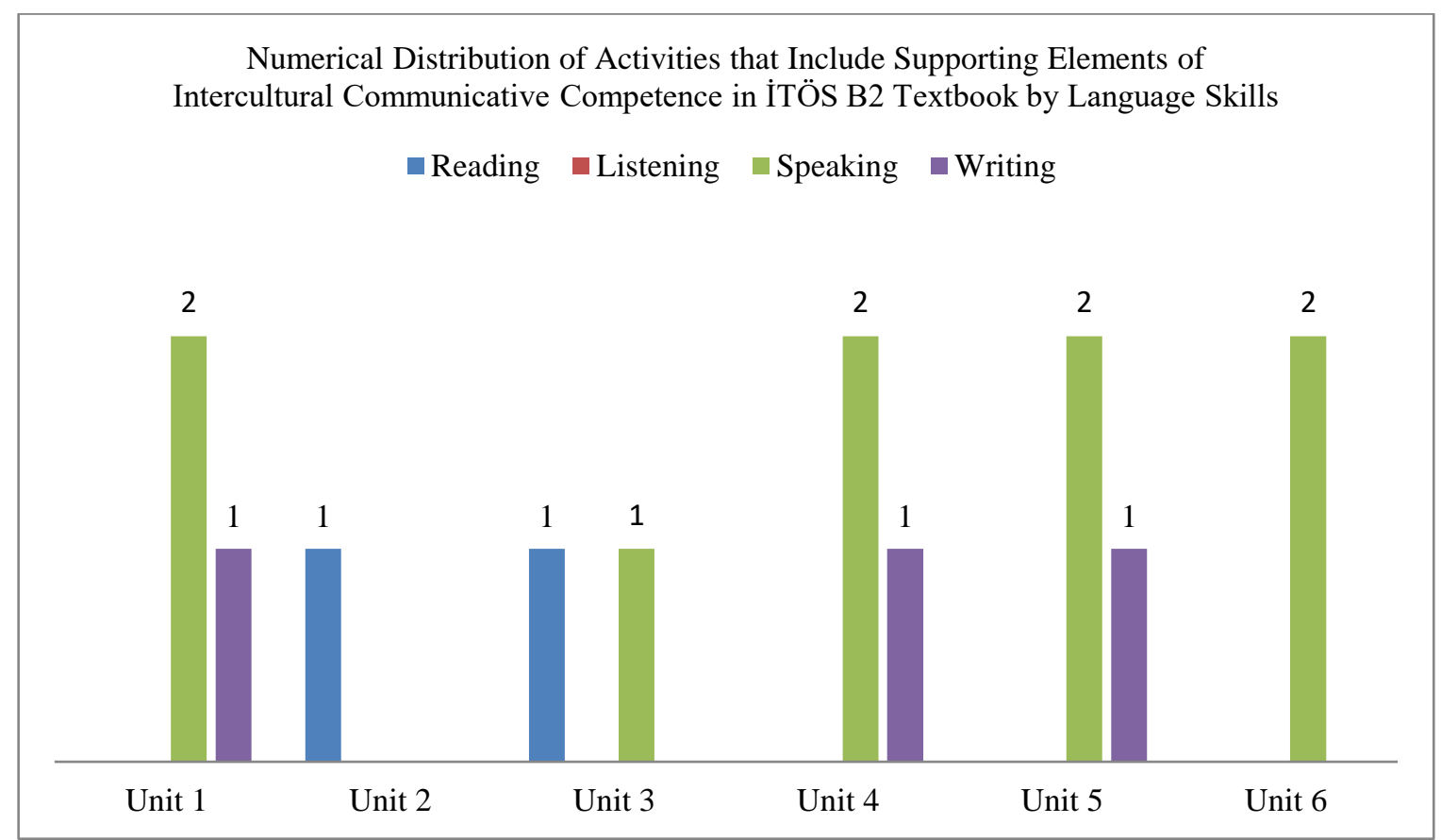

Figure 8. Numerical Distribution of Activities that Include Supporting Elements of Intercultural Communicative Competence in the İTÖS B2 Textbook by Language Skills

When the activities that support the intercultural communicative competence in the B2 Textbook of the İstanbul Yabancılar İçin Türkçe Öğretim Seti are analyzed numerically in terms of language skills, it is seen that nine of the activities belong to speaking skills, three of them to writing and two of them to reading skills. Activities that support intercultural communicative competence are not encountered in the listening skill.

\section{Percentage Distribution of Activities that Include Elements Supporting Intercultural Communicative} Competence in İTÖS B2 Textbook by Language Skills

Percentage Distribution of Activities that Include Elements Supporting Intercultural Communicative Competence in the İTÖS B2 Textbook by Language Skills

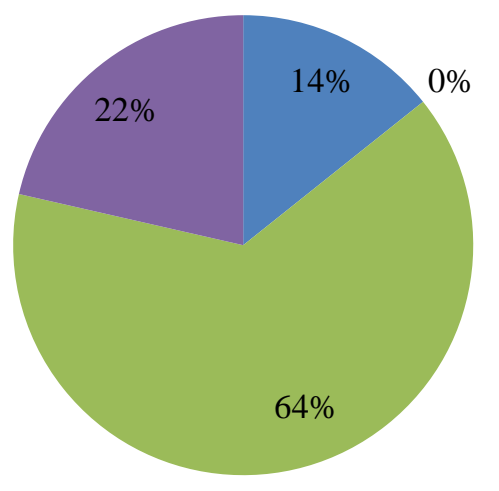

- Reading

Listening

Speaking

- Writing

Figure 9. Percentage Distribution of Activities that Include Elements Supporting Intercultural Communicative Competence in the İTÖS B2 Textbook by Language Skills

When the activities that support intercultural communicative competence in the B2 Textbook of the İstanbul Yabancılar İçin Türkçe Öğretim Seti are examined in terms of language skills, it is seen that these activities are included in the productive skills proportionally. The activities that support the intercultural 
communicative competence are mostly included in the speaking skill, but never in the listening skill. Activities supporting intercultural communicative competence were included in speaking skill with $64 \%$, writing skill with $22 \%$, and reading skill with $14 \%$, respectively, in percent value.

\section{Numerical Distribution of Activities that Include Elements Supporting Intercultural Communicative} Competence in the YİTÖS B2 Textbook

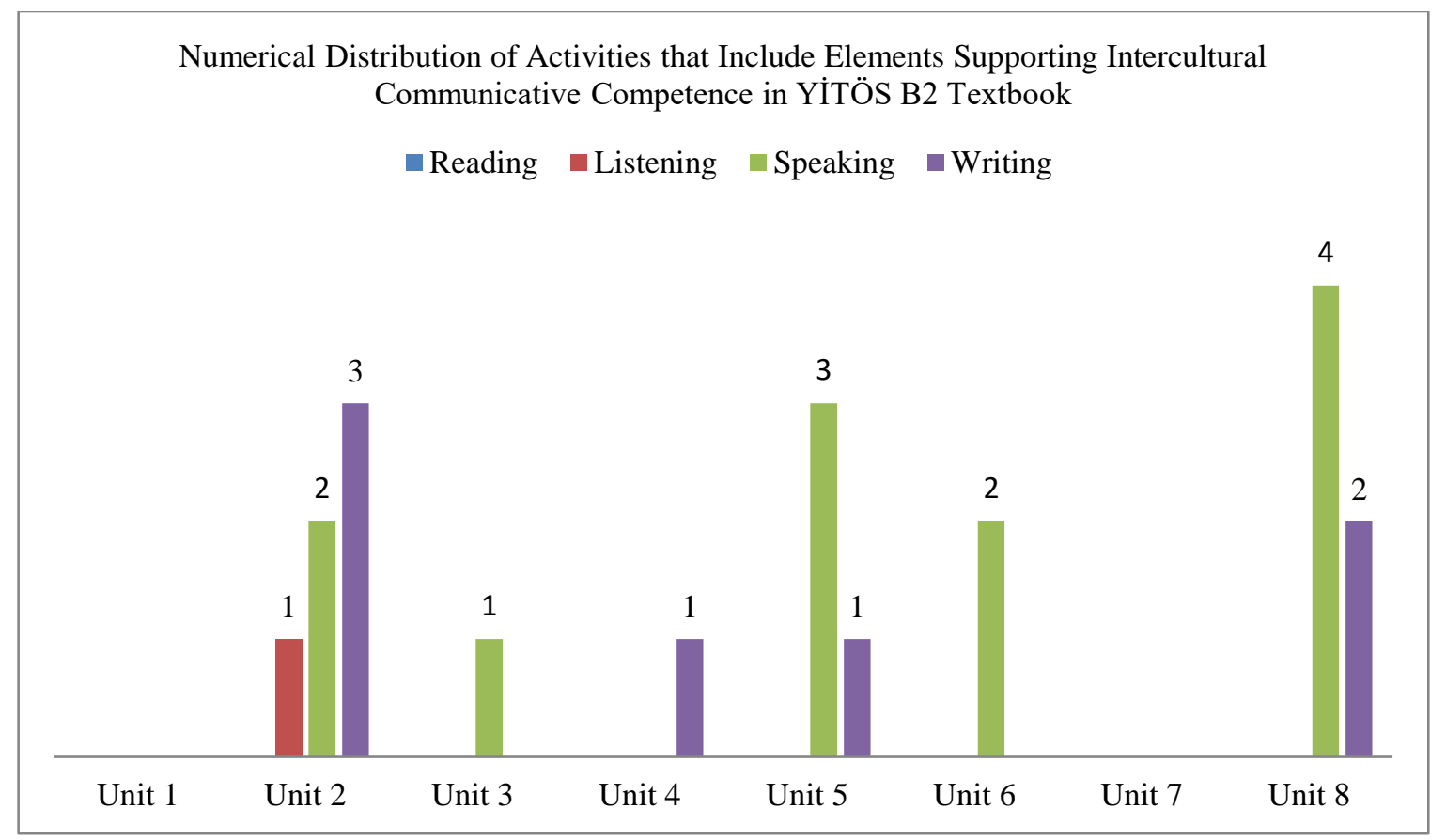

Figure 10. Numerical Distribution of Activities that Include Elements Supporting Intercultural Communicative Competence in the YİTÖS B2 Textbook

When the activities that support the intercultural communicative competence in the B2 Textbook of Yedi Iklim Türkçe Öğretim Seti are analyzed numerically in terms of language skills, it is seen that twelve of the activities belong to speaking skills, seven of them belong to writing skills, and one of them to listening skills. Activities supporting intercultural communicative competence are not included in reading skills.

\section{Percentage Distribution of Activities that Include Supporting Elements of Intercultural Communicative} Competence in the YİTÖS B2 Textbook by Language Skills

Percentage Distribution of Activities that Include Supporting Elements of Intercultural Communicative Competence in the YİTÖS B2 Textbook by Language Skills

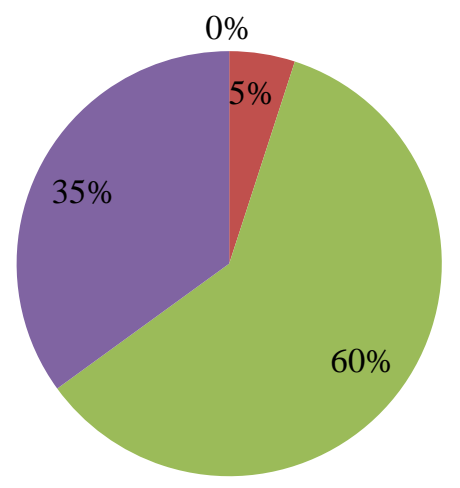


When the activities supporting intercultural communicative competence in the Yedi İklim Türkçe Öğretim Seti B2 Textbook are examined in terms of language skills, it is seen that these activities are included in the productive skills proportionally. The activities that support the intercultural communicative competence are mostly included in the speaking skill, but never in the reading skill. The activities that support the intercultural communicative competence take place in the speaking skills with $60 \%$, writing $35 \%$, and listening with $5 \%$, respectively, in terms of a percent value.

\section{Discussion and Conclusion}

Today, in foreign language teaching, while designing the syllabus, "What and to what extent can we ensure that the learner can approach a world that is foreign to him and to the people of this world without prejudice, tolerance, understanding and interest when we teach in a foreign language,? (Tapan, 1995, p. 156). In this respect, it is crucial to include elements that support intercultural communicative competence in foreign language teaching studies. Supporting intercultural communicative competence elements helps the language learner create the awareness that all cultures are valuable.

When the course books prepared for teaching Turkish as a foreign language are examined, it is seen that these teaching sets are suitable for cultural transfer. In the study conducted by Kalenderoğlu $(2015$, p. 77$)$, it was stated that the İstanbul Yabancılar İçin Türkçe Öğretim Seti is appropriate in terms of cultural elements that should be included in the textbooks specified in the European Common Framework for Languages. In the study conducted by İşcan and Yassitaş (2018, p. 64), it was stated that the textbooks of the Yedi İklim Türkçe Öğretim Seti are capable of conveying Turkish culture, too.

Although the elements of Turkish culture are emphasized in teaching sets of Turkish as a foreign language, it is seen that the importance is not given well enough to the elements that support the intercultural communicative competence. The number of activities supporting intercultural communicative competence is 14 in İTÖS B2 textbook and 20 in YİTÖS B2 textbook. While the YİTÖS B2 coursebook consists of 8 units, the İTÖS B2 coursebook consists of 6 units. When the activities in Units 7 and 8 in the YİTÖS B2 textbook are excluded from the study, it is seen that the number of activities that support intercultural communicative competence in both teaching sets is equal. The activities titled "From Culture to Culture" in the İTÖS B2 textbook have ensured that the elements supporting the intercultural communicative competence are included in each unit. The inclusion of activities titled "From Culture to Culture" in each unit shows that intercultural communicative competence is taken into account in preparing the İTÖS B2 textbook. No activity supports intercultural communicative competence in units 1 and 7 in the YİTÖS B2 textbook. This situation shows that intercultural communicative competence was not taken into account in preparing the YİTÖS B2 textbook.

The ratio of the number of activities supporting intercultural communicative competence to the total number of activities is 7\% in ITTÖS B2 textbook and 8\% in YITTÖS B2 textbook. Both teaching sets are very close to each other in terms of the ratio of activities supporting intercultural communicative competence to the total number of activities. These rates show that the elements that support the intercultural communicative competence are not adequately included in the B2 textbook in both teaching sets.

Although it is not a study that directly examines the teaching sets used in teaching Turkish as a foreign language in terms of intercultural communicative competence, some studies examine the teaching sets in cultural transfer and address intercultural communicative competence. İşcan and Yassitaş (2018, p. 64), who examined the B1 and B2 textbooks of the Yedi Iklim Türkçe Öğretim Seti in terms of cultural transfer, revealed that the textbooks were capable of achieving success in conveying Turkish culture, but had deficiencies in terms of intercultural communication. Similarly, Ökten and Kavanoz (2014, p. 845), in their study examining the teaching sets used in teaching Turkish as a foreign language in terms of cultural transfer, stated that the Turkish culture elements were insufficient to support intercultural awareness. 
When examining which language skills belong to the activities that support intercultural communicative competence in İTÖS and YİTÖS textbooks, it is seen that productive skills gain weight in both teaching sets. In the İTÖS B2 textbook, activities containing elements that support intercultural communicative competence are included in speaking skills with $64 \%$, writing skills with $22 \%$, and reading skills with $14 \%$. There are no activities in listening skills that contain elements that support intercultural communicative competence. In the YİTÖS B2 textbook, activities that support intercultural communicative competence are included in speaking skills with $60 \%$, writing skills with $35 \%$, and listening skills with $5 \%$. There are no activities in reading skills that contain elements that support intercultural communicative competence.

The fact that activities containing elements that support intercultural communicative competence dominate speaking and writing skills, which are productive skills, is highly accurate in the sense that a textbook has been prepared with an approach that supports intercultural communicative competence. The purpose of the activities used in the textbooks used in foreign language teaching is to give information and awareness about the target culture while teaching the target language's vocabulary and linguistic structures. Ensuring knowledge of the textbooks' target culture is carried out through activities related to [reading and listening] comprehension skills. After conducting an activity related to reading and listening skills that convey information about the target culture, touching on their own culture, making them feel that their culture is valuable, and thus creating the awareness of the value of all cultures in the learner enables the language learner to develop positive attitudes towards the target culture. In this sense, the development of intercultural communicative competence needs to enable learners to convey their own cultures in their own words. In addition, it is not possible to touch on the culture of all learners in reading and listening skills in classes where students from different cultures are together. 


\section{REFERENCES}

Barın, E,. Çobanoğlu, Ş., Ateş, Ş., Balcı, M., Özdemir, C. (Ed.). (2018). Yedi iklim Türkçe B2. Ankara: Başak Matbaacilik.

Baysal, E., A., \& Hocaoğlu, N. (2019). Nitel araştırma modelleri-desenleri. Ocak G. (Ed.) Eğitimde Bilimsel Araştirma Yöntemleri içinde. (s. 126-149 ), Ankara: Pegem Akademi.

Bölükbaş, F., \& Yılmaz, M., Y. (Ed.). (2017). İstanbul yabancılar için Türkçe ders kitabı B2. İstanbul: Kültür Sanat.

Canatan, K. (2009). Avrupa toplumlarında çokkültürcülük: sosyolojik bir yaklaşım. Uluslararası Sosyal Araştırmalar Dergisi. 2 (6). 80-97.

Çötok, N. A. (2010). Çokkültürlülük, kültürlerarasılık ve entegrasyon tartışmaları bă̆lamında Alman eğitiminde Türk öğreniciler: Bremen örneği. Doktora Tezi. Sakarya Üniversitesi Sosyal Bilimler Enstitüsü, Sakarya.

Erdil, M. (2018). Türkiye Cumhuriyeti Yükseköğretim Kuruluna bağlı 209 üniversitede yabancılara Türkçe öğretimi. Uluslararası Sosyal Araştırmalar Dergisi. 11 (60). 93-112

Gürbüz, S., \& Şahin, F. (2017). Sosyal bilimlerde araştırma yöntemleri felsefe - yöntem - analiz. Ankara: Seçkin.

İltar, L. (2020). Kültürlerarası iletişimsel dil yeterliği bağlamında göçmenlere Türkçe öğretimi. Başar, U., \& Tüfekçioğlu B. (Ed.) Göçmelere Türkçe öğretimi içinde. (s. 45-66 ), Ankara: Nobel.

İşcan, A., \& Yassıtaş, T. (2018). Yabancı dil olarak Türkçe öğretimi ders kitaplarında kültür aktarımı: Yedi İklim Türkçe Öğretim Seti örneği (B1-B2 düzeyi). Aydın Tömer Dil Dergisi 3 (1) 47-66.

Kalenderoğlu, İ. (2015). Türkçenin yabancı dil olarak öğretiminde kullanılan temel düzey (A1, A2) ders kitaplarında kültür aktarımı. 21. Yüzyılda Eğitim ve Toplum. 4 (12). 73-83.

Kalfa, M. (2013). Yabancılara Türkçe öğretiminde sözlü kültür unsurlarının kullanımı. Millı̂ Folklor. 25 (97). 167-177.

Kaya, A., \& Kentel, F. (2005). Euro- Türkler Türkiye ile Avrupa Birliği arasında köprü mü engel mi? Almanya-Türkleri ve Fransa-Türkleri üzerine karşılaştırmalı bir çalışma, İstanbul: İstanbul Bilgi Üniversitesi.

Korkmaz, C., B. (2019) Yabancı dil olarak Türkçenin öğretiminde kullanılan dinleme metinlerinin metin işleme süreleri , International Journal of Languages' Education and Teaching, 7(1), 121-146.

Okur, A., \& Keskin, F. (2013). Yabancılara Türkçe öğretiminde kültürel ögelerin aktarımı: İstanbul yabancılar için Türkçe öğretim seti örneği. International Journal of Social Science. 6 (2). 1619-1640.

Ökten, C., \& Kavanoz, S. (2014). Yabancı dil olarak Türkçe öğretimini hedefleyen ders kitaplarında kültür aktarımı. Turkish Studies 9 (3). 845-862.

Özbudun, S. (2014). Antropoloji gözüyle: sınıf, kültür, kimlik yazlları. Ankara: Ütopya Yayınevi.

Tapan, N. (1995). Yabancı dil olarak Almanca öğretiminde yeni bir yöneliş: kültürlerarası - bildirişim - odaklı yaklaşım. Alman Dili ve Edebiyatı Dergisi. 9. 149-168.

Toprak, F. (2011). Yabancılara Türkçe öğretimi kitaplarındaki okuma parçaları ve diyaloglar üzerine bir değerlendirme. Türkiyat Araştırmaları Dergisi. 29. 11-24.

Yıldırım, A., \& Şimşek H. (2016). Sosyal bilimlerde nitel araştırma yöntemleri. Ankara: Seçkin. 